\title{
The effects of herbal medicine on epilepsy
}

\author{
Wei Liu ${ }^{1, *}$, Tongtong Ge ${ }^{1, *}$, Zhenxiang Pan ${ }^{1}$, Yashu Leng ${ }^{2}$, Jiayin Lv² and Bingjin $\mathbf{L i}^{1}$ \\ ${ }^{1}$ Jilin Provincial Key Laboratory on Molecular and Chemical Genetic, The Second Hospital of Jilin University, Changchun \\ 130041, PR China \\ ${ }^{2}$ Third Hospital of Jilin University, Changchun 130033, PR China \\ *These authors contributed equally to this work
}

Correspondence to: Bingjin Li, email: libingjin@jlu.edu.cn

Keywords: herbal medicine, epilepsy, GABA, neuron, anticonvulsants

Received: January 25, $2017 \quad$ Accepted: March 22, $2017 \quad$ Published: April 03, 2017

Copyright: Liu et al. This is an open-access article distributed under the terms of the Creative Commons Attribution License 3.0 (CC BY 3.0 ), which permits unrestricted use, distribution, and reproduction in any medium, provided the original author and source are credited.

\section{ABSTRACT}

Traditional herbal medicine plays a significant role in the treatment of epilepsy. Though herbal medicine is widely used in antiepileptic treatment, there is a lack of robust evidence for efficacy and toxicity of most herbs. Besides, the herbal medicine should be subject to evidence-based scrutiny. In this context, we present a review to introduce the effects of herbal medicine on epilepsy. However, hundreds of herbal medicines have been investigated in the available studies. Some commonly used herbal medicines for epilepsy have been listed in our study. The overwhelming majority of these data are based on animal experiments. The lack of clinical data places constraints on the clinical recommendation of herbal medicine. Our study may conduct further studies and provide some insight on the development of antiepileptic drugs.

\section{INTRODUCTION}

Herbal medicine for epilepsy therapy is a centuriesold practiced medical form in diversified cultures [1-7]. The herbal medical traditions are reported in China, Iran, Europe, America. Chinese herbal medicine, which is significantly different from others, is timehonored tradition and based on sophisticated medical theories under-going long-term repeated confirmation. Besides, the quantity of the herbs for epilepsy in Chinese traditional herbal medicine is absolutely dominant in herbalism worldwide. Herbal medications are currently the most usual approach to complementary and alternative medications, which play an important part in the therapy to control epileptic seizures or complications caused by antiepileptic drugs [8]. The aims and attitudes of the patients with epilepsy who have access to herbal medicine in developing countries are different from those in the developed countries. The herbal medications, the most usual form of complementary and alternative medications, in developed countries are served for seizure control, reducing complications caused by antiepileptic drugs and general health maintenance, and the majority of the patients who take herbal medications do not reveal information to the physicians. The herbal therapies in developing countries are often used as a substitute for orthodox Western scientific medicine and supplementary treatment [8].

Though herbal medicine is accepted worldwide and extensively used in antiepileptic treatment, there is a lack of robust evidence for efficacy and toxicity of most herbs. The theory of traditional Chinese herbal medicine is essentially different from Western medicine. In Chinese medicine theory, the human body is not only an integral whole consist of internal organs, "channel" and fundamental substances such as essence, vital energy, blood and body fluid, but an inseparable part of outside natural world. "Channel" network connects internal organs as a functional group. So, the theories of traditional Chinese medicine are based on a philosophical system summarized by ancient people. As opposed to traditional Chinese medicine, Western medicine explores the underlying mechanism of biological activity and pathophysiological processes. Traditional Chinese medicine is often unintelligible for Westerntrained physicians and needs scientific explanations for mechanism of "channel" and active components of herbs [9]. Though herbal medicine for epilepsy is widely used, it should be subject to evidence-based scrutiny. Thousands of studies have been reported that 
herbal medicine is used for epilepsy, most of which are experimental tests in laboratory animals. However, there is still a lack of critical analysis on efficacy and adverse effects in clinical use of herbal medicine for epilepsy. It is reported that approximately $30 \%$ patients with epilepsy who take antiepileptic drugs still suffer from seizures [10]. In addition, the reasons why the patients with epilepsy take herbal medicine include economic factors, cultural attitudes toward orthodox Western scientific medicine, substitute for artificial medicine that fails to control seizure. Therefore, herbal medicine may provide high possibility for scientists to find new molecular mechanism of epilepsy and new antiepileptic drugs. In this context, we present a review to introduce the effects of herbal medicine on epilepsy.

\section{Traditional herbal medicine for epilepsy in regions}

\section{Traditional herbal medicines for epilepsy in Asia}

\section{Iranian traditional herbal medicine for epilepsy}

Iranian traditional medicine has a long history of herbal therapies for ailments, including convulsive seizures treatment. There are many Iranian traditional medicine books recording herbal medicine for epilepsy. A recent study has reviewed the herbal medicine for epilepsy recorded in five famous Iranian traditional medicine books [11]. The study has listed twentyfive herbal medicine for epilepsy for these books, and detailed the information about anticonvulsant effects of eleven herbals: paeonia officinalis, bryonia alba, lavandula stoechas, ferula persica willd, ferula asafoetida, coriandrum sativum, caesalpinia bonducella roxb, ferula gummosa boiss, cuscuta epithymum murray, cedrus deodara loudon, and origanum majorana. The extracts of used parts from most of these eleven herbal medicines exhibit antiepileptic effects on seizure animal models, while neighter ferula asafoetida nor ferula gummosa boiss can prevent pentylenetetrazol-induced seizures $[11,12]$. In the mentioned data, some molecular mechanisms have been researched, as follows: the anticonvulsant activity of ethanolic extract of the aerial parts of bryonia alba results from its moderate affinity to the benzodiazepine-site of the gamma amino butyric acid (GABA) receptor [11], the aqueous-methanolic extract of lavandula stoechas may act as a calcium channel blocker [13], and the petroleum ether extract of caesalpinia bonducella may block the chloride ion channel linker to GABA receptors [14]. Besides, methanol Ferula extracts may have cytotoxic activity [12]. However, the lack of data and detailed information of herbal clinical medication on patients with epilepsy remains limited for herbal therapies and need to be further investigated.

Lavandula officinalis is another common herb used for epilepsy in Iranian traditional medicine. Some studies have suggested that it exhibits anticonvulsant effects on both pentylenetetrazol-induced seizures animal models and pentylenetetrazol kindling seizures in animal models $[15,16]$. Besides, it is reported that it can protect cerebellar granular cells from glutamateinduced neurotoxicity [18]. The possible mechanisms of its antiepileptic effect have been demonstrated in some studies: inhibition of glutamate release, enhancement of GABA receptors [15], blockade of calcium channel, and its antioxidant effect [17-19]. The results indicate that Lavandula officinalis has huge potential for research and development of antiepileptic drugs.

\section{Zizyphus jujube}

Zizyphus jujube is used as an anticonvulsant in traditional medicine in India. Many studies have proven the antiepileptic properties in animal models assay $[20,21]$. The hydroalcoholic extract of fruits of Zizyphus jujuba can decrease pentylenetetrazol- and MESinduced seizures in rats. Besides, the hydroalcoholic extract strongly enhances the anticonvulsant effects of phenytoin and phenobarbitone without serum level alternation of both drugs in combination therapy [21]. The antiepileptic effect may be mediated by inhibition of glutamate-induced over excitation, reduction of synaptic release of glutamate or NMDA (N-methyl-Daspartate), or reversion antioxidant-oxidant imbalance $[20,21]$. Moreover, zizyphus jujube can improve seizure-associated cognitive impairment and oxidative stress in rats [20]. However, these mechanisms have not been well evaluated.

\section{Taxus wallichiana Zucc (Himalayan Yew)}

Taxus wallichiana Zucc (Himalayan Yew) is a common native herbal medicine used in the northern areas of Pakistan and Nepal for epilepsy, though there is a lack of sufficient evidence on the anticonvulsant activities [22]. The anticonvulsant effect of Taxus wallichiana Zucc is firstly reported in a scientifically designed study in 1997, and demonstrates in pentylenetetrazol-induced seizures models by a recent study [23]. The mechanisms of anticonvulsant effect remain unknown, but there is potential to control myoclonic and absence seizures still leaving room for further studies.

\section{Ganoderma lucidum}

Ganoderma lucidum is a popular traditional herbal medicine for ailments in traditional Chinese medicine. Some studies conducted by a research team have revealed that Ganoderma lucidum spore has antiepileptic properties in in vivo and in vitro studies [24-27]. Ganoderma lucidum spore inhibits the expression of $N F-\kappa B$ in the brain of rats with epilepsy and the expression of N-Cadherin in hippocampal neurons, while enhancing neurotrophin-4 expression in hippocampal neurons [24]. The results from 
a recent research suggest that the antiepileptic effects of Ganoderma lucidum spore may also result from inhibition of the $\mathrm{Ca}^{2+}$ accumulated in epileptic hippocampal neurons and subsequent stimulation of CaMK II $\alpha$ expression [28]. Though there is no report in our knowledge on the information of clinical use of Ganoderma lucidum spore, these studies indicate the potential of Ganoderma lucidum spore in the treatment of patients with epilepsy.

\section{Salvia miltiorrhiza (Danshen or Chinese red sage)}

Salvia miltiorrhiza is a traditional herbal medicine used for treating epileptic seizures in traditional Chinese medicine. Acetonic crude extracts of salvia miltiorrhiza have significant anticonvulsant efficacy in larval zebrafishpentylenetetrazol models [10]. The active components are hydrophobic tanshinones, such as miltirone, 15, 16- Dihydrotanshinone I, cryptotanshinone, and tanshinone IIA. Compared with the other tanshinones, tanshinone IIA also exhibits anti-seizure effects on pentylenetetrazol induced mouse models and no sedative effects. The antiseizure properties of tanshinone result from an interaction tendency with pathways irrelevant to GABA and related agonists [10]. The recent studies on tanshinones make it possible to be a potential anti-seizure drug.

\section{Uncaria rhynchophylla}

Uncaria rhynchophylla is another common herbal medicine in traditional Chinese medicine used for epilepsy. The antiepileptic effects of uncaria rhynchophylla have been seen in kainic acid-induced epileptic seizures models [29-31]. There are several compounds found in Uncaria rhynchophylla, and the neuroprotective related compounds of those are rhynchophylline and isorhynchophylline $[32,33]$. Studies indicated that the anticonvulsant effects on kainic acid-induced epileptic seizures may be medicated by the regulation of immune response and neurotrophin signaling pathway, and inhibition of gene expression: neuron survival brain-derived neurotrophin factor (BDNF) gene and inflammation gene IL-1 $\beta$ [34]. Better yet, this study details the investigations of signal pathway and the studies on targets through genomics and immunohistochemistry, and it can bring some illumination to the mechanisms of research on antiepileptic herbal medicine.

\section{Compound herbal medicine}

Anti-epilepsy capsules (Kang Xian capsules), a compound of Shi Chang Pu(Rhi- zoma Acori Tatarinowii), Dan Nan Xing( Arisaema cum Bile), Tian Ma (Rhizoma Gastrodiae), Tai Zi Shen (Radix Pseudostellariae), Fu Ling (Poria), Chen Pi (Pericar- pium Citri Reticulatae), Ban Xia (Rhizoma Pinelliae), Zhi Qiao (Fructus Aurantii) and Chen Xiang (Lignum Aquilariae Resinatum), are clinically used for children epilepsy [35]. The clinical study of antiepilepsy capsules on childhood epilepsy cases showed
$57.4 \%$ cases were markedly effective, $25.9 \%$ effective, $10.3 \%$ improved, 5\% ineffective and 1\% aggravated. The total effective ratio was up to $83.3 \%$. Besides, the frequency and duration of epilepsy had significantly decreased after taking anti-epilepsy capsules.

However, there are discrepancies between the effects of capsules on different types of epilepsy: better effects on autonomic epilepsy, and epilepsy caused by wind, phlegm, and terror while poor on paroxysmal epilepsy and epilepsy resulted from blood stasis. The antiepileptic effects of capsules are mediated by prolonging the attenuation duration of NMDA receptor channels, altering the expression of NMDA receptor subunits, and reducing in the concentration of intraneuronal $\mathrm{Ca}^{2+}$ inside the hippocampal neurons [36].

\section{Traditional herbal medicines for epilepsy in Africa}

\section{Acanthus montanus, et al}

Herbal medicine is a common approach for epilepsy in traditional African medicine. It is reported that at least 43 plants have been traditionally used for epilepsy and convulsions, and the well-known herbal medicines include Acanthus montanus (Acanthaceae), Alchornea laxiflora (Euphorbiaceae), Hyptis spicigera (Lamiaceae), Microglossa pyrifolia Kuntze (Asteraceae), Piliostigma reticulatum (Ceasalpiniceae), and Voacanga africana (Apocynaceae) [37]. However, there are few researches on antiepileptic effects of the six cited plants. A recent study has investigated the extracts of these plants in several epilepsy relevant animal models [37]. The results suggest that there are different effects shown in these extracts. All extracts of the six plants inhibit strychnine-induced seizures, and Hyptis spicigera is the most effective. Five plants except Alchornea laxiflora decrease pentylenetetrazol-induced convulsions, with Hyptis spicigera being the most effective as well. The extracts of Acanthus montanus, Microglossa pyrifolia, and Voacanga africana prolong the time to the onset of convulsions induced by isonicotinic hydrazide acid and inhibit MES (maximal electroshock)-induced convulsions [37]. Besides, both the first two plants also exhibit significant anticonvulsant effects in picrotoxin-treated mouse [37]. Pharmacological diversities of these plants are mediated through a variety of mechanisms. The anticonvulsant effects of Alchornea laxiflora, Microglossa pyrifolia, Piliostigma reticulatum, and Voacanga Africana may result from antagonistic action on NMDA receptors. The antagonism of isonicotinic hydrazide acid- and pentylenetetrazol-induced seizures shown in the plant extracts may be mediated by interaction with GABAergic neurotransmission [38]. The protective effects against MES-induced convulsions are probably due to prolonging the inactivation of sodium channels [39]. A study on 
screen of traditional herbal medicines for epilepsy binding $\mathrm{GABA}_{\mathrm{A}}$-benzodiazepine receptor assay suggests that some plants have shown to be active in binding to the $\mathrm{GABA}_{\mathrm{A}}$ benzodiazepine receptor [40]. Though these results have made progress in Africa herbal medicine on epilepsy, the sophisticated analyses need to be further strengthened.

\section{Ficus platyphylla}

Ficus platyphylla is used in Nigeria's traditional medicine for epilepsy, especially northern Nigeria [41-44]. The efficacies of the plant are widely accepted in Nigeria's folk and the oral administration of the methanol extract of Ficus platyphylla stem bark is proven to have anticonvulsant effects and be safe in rats [44]. A recent scientific study has tested the extract in several animal seizures models (pentylenetetrazole-, strychnine-, picrotoxin-, isonicotinic hydrazide acid-, aminophyllineand MES- induced seizures) [41]. The psychoactive agents of the extract include saponins, flavonoids and tannins. The extract exhibits anti-seizure effects in pentylenetetrazoland strychnine-induced seizures models, but fails to treat against sonicotinic hydrazide acid-, aminophylline-, and MES-induced seizures. Meanwhile, the extracts significantly delayed the latencies of myoclonic jerks and all models of seizures except MES-induced seizures. Besides, the extract can improve the learning impairment and ameliorate the neuronal cell loss in the cornu ammonis 1 and cornu ammonis 3 regions of hippocampus [42]. Possible mechanisms of antiepileptic activity mediated by the extract may attribute to inhibit of T-type $\mathrm{Ca} 2+$ currents, block glutamatergic neurotransmission mediated by the NMDA receptor, interfere with postsynaptic inhibition mediated by glycine, an important inhibitory transmitter to motor neurons and interneurons in the spinal cord, scavenge action of free radicals (such as reactive oxygen and nitrogen species), affinity for GABAergic and glutamatergic receptors, and reduction of glutamate release $[41,42]$. The toxicity tests in rats showed that there were no toxic effects of the extract on rats, so it may be a potential drug for patients with epilepsy [41-44]. Nevertheless, there is no literature to show its efficiency in clinical trial.

\section{Gladiolus dalenii (Iridaceae)}

Gladiolus dalenii is another common traditional herbal medicine in Africa. The extract of Gladiolus dalenii is reported that it has a strongly anticonvulsant property in pentylenetetrazol-induced seizures by modulatory reaction on $\mathrm{GABA}_{\mathrm{A}}$ receptor, and it can significantly decrease MES-induced seizures in animal models mediated through prolonging the inactivation of sodium channels [45-47]. Besides, Gladiolus dalenii also possesses a sedative property, and exerts a synergistic effect when combining medication with diazepam. There is no significant acute toxicity effect found at a dose less than $4 \mathrm{~g} / \mathrm{kg}$ after oral administration in rats. The adverse effects, including hypoactivity, asthenia, and salivation, will happen at a higher dose than $4 \mathrm{~g} / \mathrm{kg}$ [47].

\section{Traditional herbal medicines for epilepsy in America}

\section{United States traditional herbal medicine for epilepsy}

As a common approach of complementary and alternative medications, traditional herbal medicine has a place in modern antiepileptic medical practice of United States [8]. The efficacy data of herbal medicine for epilepsy have been documented in available medicine literature. The total costs of herbal medicines in United States sum up to 690 million dollars. The herbs used for epilepsy in United States include American hellebore (Veratrum viride), betony (Stachys officinalis), Blue cohosh (Caulophyllum thalictroides), Kava (Piper methysticum), Mistletoe (Viscum sp), Mugwort (Artemisia vulgaris), Pipsissewa (Chimaphila umbellate), skullcap (Scutellaria laterifolia and $S$ baicalensis), Valerian (Valeriana officinalis) [48-50]. Though these herbs have been used to treat epilepsy in humans, most of them have not been proven in clinical assay, even not in laboratory animal test. As the antiepileptic effects of skullcap and Valerian have been reviewed in our study above, Mistletoe and Kava also have shown positive effects in laboratory animal assay. However, the lack of clinical data places constraints on the clinical recommendation of herbal medicine [48]. Hence, the patients with epilepsy who have received herbal medication should be encouraged to report the drug response, including efficacy and adverse effects. However, further investigations should more focus on both basic and clinical data.

\section{Other commonly used herbal medicines}

\section{Cannabis}

Medical use of cannabis dates back to 2700 years before Common Era, and its use for epilepsy were reported in medieval times and late 19th century [51]. In these times, though anecdotal effective for epilepsy, there were no well-controlled trials to examine, so the use of cannabis for epilepsy remained questionable [51]. Despite presence of varying degrees defects, some recent studies, the results of which have been reviewed, have supported the antiepileptic effects of cannabis [51-57]. The antiepileptic ingredients of cannabis include $\Delta^{9}$-tetrahydrocannabinol, $\quad \Delta^{9}$-tetrahydrocannabivarin, cannabidiol, cannabinol, and cannabidivarin, and all of them act on multiple receptor targets [51]. $\Delta^{9}$ tetrahydrocannabinol and $\Delta^{9}$-tetrahydrocannabivarin (the propyl variant of $\Delta^{9}$-tetrahydrocannabinol) are main 
psychoactive agents of the ingredients of cannabis, and both of them show anti-seizure effect on acute generalized seizure models, including MES- and pentylenetetrazol-induced seizures. However, not all studies agree with the results. Some studies found that $\Delta^{9}$-tetrahydrocannabinol made no positive effect on some seizure animal models, and it induced epileptic form activity [51]. Cannabidiol has been confirmed by recent studies that it has antiepileptic and anticonvulsant effects in acute models of seizure, but the detail mechanisms remain partly known [58-60]. The effects of cannabidiol on seizure may differ in types of seizure models. Some studies indicate that cannabidiol may make positive effects and well tolerated in the treatment of refractory pediatric epilepsy [55]. There are two retrospective cohorts of cannabidiol products used for children epilepsy [55, 56]. In Craig A. Press' study, 43 patients (57\%) reported improvement in seizures, 33\% patients improved alertness/behavior, $11 \%$ patients improved motor skills and language, $7 \%$ patients improved sleep, and $44 \%$ patients suffered from side effects. In Shaun A' study, 100 $(85 \%)$ patients reported a decrease in seizure frequency, including 16 (14\%) reporting complete seizure freedom. Side effects during cannabidiol exposure are significantly lower than those before cannabidiol exposure. Besides, improvement in sleep (53\%), alertness (71\%), and mood $(63 \%)$ was reported. Notably, the vast majority (93\%) of the respondents would like to continue taking cannabidiol products after survey completion.

Despite being well tolerated in humans, whether cannabidiol can use for patients with epilepsy is still a problem. cannabidivarin, the propyl variant of cannabidiol neglected before, has been found to show prominent anticonvulsant effects on seizures of animal models, besides, no significant adverse effects occur at anticonvulsant dose of cannabidivarin [54]. The study also investigated the combination effects of cannabidivarin and antiepileptic drugs in seizure models, and the combination significantly decreased seizure severity and the occurrence of severe seizures, and there was no significant positive or negative interaction at experiment dose. At high dose $1500 \mathrm{mg} /$ day (p.o.) or $30 \mathrm{mg}$ (i.v.), no significant adverse effects were seen in both acute and chronic medication [61]. Long term administration of cannabidiol may cause immunosuppression in human [51]. The anticonvulsant mechanisms of cannabis may attribute to promoting cannabinoid receptor type 1 expression and localization on different presynapses (i.e. excitatory or inhibitory), inhibiting GABAergic circuits in brain areas crucial to epileptogenesis, and inhibiting

diacylglycerol lipase $\alpha$, an enzyme responsible for the production of the endocannabinoid 2-arachidonoylglycerol, to increase the number of cannabinoid receptor type 1 at the membrane $[52,53]$. These results indicate that cannabidivarin has potential to treat seizures and may provoke further studies of cannabidivarin on seizures.

\section{Ginseng}

Ginseng is one of the most common herbal medicines used for ailments in China, Korea and America. Some studies have shown that ginsenosides play a significant role in most pharmacological effects of ginseng, including anti-inflammatory and neuroprotective effects [62-64]. Both single and chronic administration of ginseng extracts can reduce the development of neurodegeneration, inflammation and larger permeability caused by status epilepticus particularly in the hippocampus at the initial days, but cannot completely reverse the reduction of hippocampal volumes in rats for a month after status epilepticus [63]. Chronic administration of ginseng extract on rats exhibited no toxic effects, but high dose more than $150 \mathrm{mg} / \mathrm{kg}$ treatment on rats increased mortality rate after status epilepticus induced by pilocarpine [63]. It is reported that Korean red ginseng extracts also significantly increase the electrical seizure threshold in rat offspring [63]. Some studies on the neuroprotective mechanisms of ginsenosides indicate that ginsenosides inhibit NMDAdependent and status epilepticus induced $\mathrm{Ca}^{2+}$ influx, and L-type $\mathrm{Ca}^{2+}$ channels in hippocampal neurons $[62,65,66]$.

\section{Pimpinella anisum}

Pimpinella anisum is distributed to the eastern Mediterranean region and Asia. It is reported that Pimpinella anisum has been used for epilepsy from medieval ages in Persian medicine [67]. The recent data suggest the anticonvulsant effects of anise oil in pentylenetetrazol- and MES-induced seizures animal models $[68,69]$. A study investigated the anticonvulsant effects of three different concentrations of anise oil ( $1 \mathrm{ml} / \mathrm{kg}, 2 \mathrm{ml} / \mathrm{kg}$, and $3 \mathrm{ml} / \mathrm{kg}$ ) [69]. Anise oil at all the three concentrations shows significantly anti-seizure properties in pentylenetetrazol-induced models. The antiseizure activity may be mediated through activation of $\mathrm{GABA}_{\mathrm{A}}$ receptors [70]. The main ingredients in anise oil include trans-anethole $(89.1 \%)$, estragol $(3.6 \%)$, linalool (1.1\%), $\alpha$-terpineol $(0.2 \%)$ and cis-anethole $(0.2 \%)$, but all ingredients are possibly responsible for the antiseizure effect. Further evaluations should be made on this problem.

\section{Passiflora invarnata (purple passion flower)}

Passiflora invarnate, a local American plant, is firstly used for epilepsy by native Americans, and its medicinal value is widely accepted by modern western medicine [71]. Some studies have shown the anticonvulsant efficacy of passiflora extracts $[71,72]$. However, the active ingredients of passiflora have not been well defined. Though most available data indicate flavonoids may be the true active ingredients of passiflora [54], the latest study suggests passiflora bioactivity attributes to compound actions of 
several ingredients rather than signal flavonoid [72]. The mechanisms may include a combination of GABA with additional ingredients facilitating its membrane permeation, and second order positive modulation of $\mathrm{GABA}_{\mathrm{A}}$ receptors by flavonoids [72, 74, 75]. Besides, the results of this study also indicate that passiflora extracts only have anticonvulsant and anxiolytic effects and no sedation and anxiogenic effects, contrasting to benzodiazepines [72]. The pharmacological effects and mechanisms of passiflora require further determination.

\section{Skullcap}

There are two species of skullcap plants family used as herbal medicine, and both have anticonvulsant effects. American skullcap is traditionally used on epilepsy by Native Americans and Europeans [76]. Baikal skullcap is a common herbal medicine of traditional Chinese medicine for ailments other than epilepsy, and exhibits neuroprotective and anticonvulsant properties in some recent studies [77, 78]. A latest study has demonstrated that the extracts of American skullcap show modest anticonvulsant efficacy in pentylenetetrazolinduced models, and confirmed the effective dose range $(60-150 \mathrm{mg} / \mathrm{kg})$ and the maximum effective dose $(90 \mathrm{mg} / \mathrm{kg})$ as well [78]. There are 12 constituents isolated and purified from the whole extracts of American skullcap: 10 flavonoids and 2 phenylethanoid glycosides. The existing flavonoids in both Baikal skullcap and American skullcap may be the active ingredients contributing to the anticonvulsant effects, which may result in high affinity for $\mathrm{GABA}_{\mathrm{A}}$ receptor and neuroprotective effects [77-79]. Further investigations of American skullcap and Baikal skullcap may draw some light on the development of epilepsy drugs.

\section{Viscum album (Loranthaceae)}

Viscum album is a native plant in Europe and Northern Asian countries, and is widely used as a herbal medicine for ailments in the folk medicine [80, 81]. It is traditionally reputed against epilepsy. Viscum album is reported that it exhibits significant antiepileptic effects in MES-, isonicotinic hydrazide acid-, and pentylenetetrazolinduced seizures model [82]. These neuroprotective properties possibly result from facilitation of GABA transmission. Though there are lots of ingredients found in Viscum album, no agents have been reported responsible for the antiepileptic effect.

\section{Zingiber officinale Roscoe (ginger)}

Zingiber officinale Roscoe is often used as a condiment in many countries, in some of which, it also acts as a treatment for ailments; for instance, colds, arthritis, migraines, hypertension, and so on [83-86]. One recent study on the anticonvulsant effects of ginger in timed intravenous pentylenetetrazol-induced seizure mice models has shown that different doses of ginger extracts significantly increased the threshold for the myoclonic seizures and forelimb tonic extension in comparison with control groups and be irrelative to the pentylenetetrazol intravenous time, while only higher dose of ginger significantly increased the threshold for the generalized clonic seizures [87]. The study hypothesizes that the mechanisms of anticonvulsant effects of ginger may attribute to antioxidant mechanisms, oxidative stress inhibition, calcium channels blockade, inhibiting NO production and reduces iNOS in lipopolysaccharidestimulated mouse macrophages, levating intracellular cGMP level, and inhibiting chloride ion channel in the complex of GABA $_{A}$ receptors [87-90]. The antioxidant ingredients in ginger include gingerols, shogaols and some phenolic ketone derivatives [87]. However, the precise molecular mechanism of anticonvulsant effects of ginger need further exploration.

\section{DISCUSSION}

As mentioned above, though some herbal medicines are clinically used for epilepsy, there is a lack of clinical data. The antiepileptic efficiency and mechanism of herbal medicine are mostly tested in animal models. Though some antiepileptic mechanisms of herbal medicines have been revealed in available literature, there are still so many issues to explore.

The antiepileptic and anticonvulsive mechanisms of most herbal medicines reviewed in our paper are further described in details and summarized in Table 1. While many herbals have multiple action targets and mechanisms, some are reported to express antiepileptic effect by single mechanism, but it does not mean the only way. The potential action targets related to antiepileptic and anticonvulsive effects contain neurotransmitter and receptor systems (such as GABA and GABA receptors, Glutamate and Glutamate receptor), ion channels (such as Calcium channel, Sodium channel and Chloride ion channel linked to GABA receptors), antioxidant effect, immune regulating, specific receptors (such as cannabinoid receptor type 1), gene expression, other active substances (such as neurotrophin-4, N-Cadherin, diacylglycerol lipase $\alpha$, and $\mathrm{CaMK} \mathrm{II} \alpha$ ).

GABA and GABA receptors, which mediate antiepileptic effects of many herbal medicines, are one of the important targets well documented in the literature. GABA, as the main endogenous inhibitory neurotransmitter, can produce inhibitory postsynaptic potentials and can be a natural anticonvulsant. The effect of herbal medicine on GABA and GABA receptors is an enhancement in receptor sensitivity for endogenous GABA 
Table 1: The anticonvulsive and antiepileptic mechanism of herbal medicine

\begin{tabular}{|c|c|c|c|c|c|}
\hline Herbal Medicine & Region & $\begin{array}{l}\text { Cells/Animals/ } \\
\text { Humans }\end{array}$ & Seizure Model & Action Target & Mechanism \& Ref. \\
\hline Apocynaceae & Africa & $\begin{array}{l}\text { In vitro model } \\
\text { (cerebral cortex from } \\
\text { rats) }\end{array}$ & - & GABAA receptor & Enhances GABA's affinity to the GABAA-receptor [37-38]. \\
\hline Bryonia alba & Iran & $\begin{array}{l}\text { In vitro model } \\
\text { (cerebral cortex from } \\
\text { rats) }\end{array}$ & - & $\begin{array}{l}\text { Benzodiazepine site on the } \\
\text { GABAA receptor }\end{array}$ & Enhances the receptor sensitivity for endogenous GABA [11] \\
\hline $\begin{array}{l}\text { Caesalpinia } \\
\text { bonducella }\end{array}$ & Iran & Animal model(mice) & $\begin{array}{l}\text { MES } \\
\text { Pentylenetetrazol } \\
\text { Picrotoxin }\end{array}$ & $\begin{array}{l}\text { Chloride ion channel } \\
\text { linked to GABA receptors }\end{array}$ & Blocks chloride ion channel linked to GABA receptors [14]. \\
\hline \multirow[t]{3}{*}{ Cannabis } & $\begin{array}{l}\text { Asia, Europe } \\
\text { and so on }\end{array}$ & $\begin{array}{l}\text { In vivo and in vitro } \\
\text { models }\end{array}$ & $\begin{array}{l}\text { Pentylenetetrazol } \\
\text { Pilocarpine }\end{array}$ & cannabinoid receptor type 1 & $\begin{array}{l}\text { Promotes cannabinoid receptor type } 1 \text { expression and } \\
\text { localization on different presynapses (i.e. excitatory or } \\
\text { inhibitory) [52]. }\end{array}$ \\
\hline & & & & GABAergic circuits & $\begin{array}{l}\text { Inhibits GABAergic circuits in brain areas crucial to } \\
\text { epileptogenesis }[52,53] \text {. }\end{array}$ \\
\hline & & & & Diacylglycerol lipase $\alpha$ & $\begin{array}{l}\text { Inhibits diacylglycerol lipase } \alpha \text {, which is the enzyme } \\
\text { responsible for the production of the endocannabinoid } \\
2 \text {-arachidonoylglycerol, to increase the number of cannabinoid } \\
\text { receptor type } 1 \text { at the membrane [52]. }\end{array}$ \\
\hline \multirow[t]{2}{*}{$\begin{array}{l}\text { Compound herbal } \\
\text { medicine }\end{array}$} & China & humans & - & NMDA receptors & $\begin{array}{l}\text { Prolong the attenuation duration of NMDA receptor channels } \\
\text { and alter the expression of NMDA receptor subunits [36]. }\end{array}$ \\
\hline & & & & Calcium channel & $\begin{array}{l}\text { Reducing in the concentration of intraneuronal } \mathrm{Ca} 2+\text { inside the } \\
\text { hippocampal neurons [36]. }\end{array}$ \\
\hline Euphorbiaceae & Africa & $\begin{array}{l}\text { In vitro model } \\
\text { (cerebral cortex from } \\
\text { rats) }\end{array}$ & - & GABAA receptor & Enhances GABA's affinity to the GABAA- receptor [40]. \\
\hline \multirow[t]{6}{*}{ Ficus platyphylla } & Nigeria & Animal model(mice) & Pentylenetetrazol & Calcium channel & Inhibition of T-type $\mathrm{Ca}^{2+}$ currents [41]. \\
\hline & & & Aminophylline & NMDA receptor & $\begin{array}{l}\text { Blocks glutamatergic neurotrans- mission mediated by the } \\
\text { NMDA receptor [41]. }\end{array}$ \\
\hline & & & $\begin{array}{l}\text { Picrotoxin } \\
\text { Strychnine }\end{array}$ & Glycine & $\begin{array}{l}\text { Interference with postsynaptic inhibition mediated by glycine, } \\
\text { an important inhibitory transmitter to motor neurons and } \\
\text { interneurons in the spinal cord [41]. }\end{array}$ \\
\hline & & & Isonicotinic hydrazide acid & Free radicals & $\begin{array}{l}\text { Scavenging action of free radicals (such as reactive oxygen } \\
\text { and nitrogen species) [41]. }\end{array}$ \\
\hline & & & & GABAergic & Affinity for GABAergic [42]. \\
\hline & & & & Glutamatergic receptors & $\begin{array}{l}\text { Affinity for glutamatergic receptors, and reduction of } \\
\text { glutamate release [42]. }\end{array}$ \\
\hline \multirow[t]{4}{*}{ Ganoderma lucidum } & China & $\begin{array}{l}\text { In vivo and in vitro } \\
\text { models }\end{array}$ & - & Neurotrophin-4 & $\begin{array}{l}\text { Promotes NT-4 expression, NT-4 can promote neuron survival, } \\
\text { alleviate neuronal injuries, inhibit neurons from apoptosis and } \\
\text { adjust the synapses plasticity [24]. }\end{array}$ \\
\hline & & & & $\mathrm{N}$-Cadherin & $\begin{array}{l}\text { Indirectly inhibits mossy fibers sprouting and adjust the } \\
\text { synaptic reconstructions by inhibiting the expression of } \\
\text { N-Cadherin [24]. }\end{array}$ \\
\hline & & & & $\begin{array}{l}\text { Epileptic hippocampus } \\
\mathrm{Ca}^{2+} \text { concentration }\end{array}$ & $\begin{array}{l}\text { Inhibits calcium overload to prevent an epileptic episode } \\
\text { induced by } \mathrm{Mg} 2+\text { deficiency [28]. }\end{array}$ \\
\hline & & & & CaMK II $\alpha$ expression & $\begin{array}{l}\text { Promotes the expression of CaMK II } \alpha \text { to prevent the onset } \\
\text { of epilepsy [28]. }\end{array}$ \\
\hline Ginseng & $\begin{array}{l}\text { America,China } \\
\text { and so on }\end{array}$ & Animal model(rats) & MES & $\mathrm{Ca}^{2+}$ influx and channels & $\begin{array}{l}\text { Inhibits NMDA-dependent and status epilepticus induced } \\
\mathrm{Ca} 2+\text { influx, and L-type } \mathrm{Ca} 2+\text { channels in hippocampal } \\
\text { neurons }[62,65,66] \text {. }\end{array}$ \\
\hline \multirow[t]{3}{*}{ Gladiolus dalenii } & Africa & Animal model(mice) & MES & $\mathrm{GABA}_{\mathrm{A}}$ receptor & $\begin{array}{l}\text { Interacts with the GABAA neuro-transmission specifically } \\
\text { through the benzodiazepine site receptor [47]. }\end{array}$ \\
\hline & & & Pentylenetetrazol & & Increase of the GABA brain content [47]. \\
\hline & & & & Sodium channe & Prolongs the inactivation of sodium channel [47]. \\
\hline Lamiaceae & Africa & $\begin{array}{l}\text { In vitro model } \\
\text { (cerebral cortex from } \\
\text { rats) }\end{array}$ & - & $\mathrm{GABA}_{\mathrm{A}}$ receptor & Enhances GABA's affinity to the GABAA-receptor [40]. \\
\hline \multirow[t]{3}{*}{ Lavandula officinalis } & Iran & $\begin{array}{l}\text { Animal model (male } \\
\text { mice) }\end{array}$ & Pentylenetetrazol & Glutamate release & $\begin{array}{l}\text { Prevents glutamate induced neurotoxicity of cerebellar } \\
\text { granular cell culture of rat pups }[18,19] \text {. }\end{array}$ \\
\hline & & & & GABA receptors & Enhance of GABA receptors [15]. \\
\hline & & & & Calcium channel & Block calcium channel $[17,18]$. \\
\hline
\end{tabular}




\begin{tabular}{|c|c|c|c|c|c|}
\hline Lavandula stoechas & Iran & Animal model(mice) & Pentylenetetrazol & Calcium channel & Blocks calcium channel [13]. \\
\hline Passiflora invarnate & $\begin{array}{l}\text { America and } \\
\text { Europe }\end{array}$ & $\begin{array}{l}\text { In vivo and in vitro } \\
\text { models }\end{array}$ & Pentylenetetrazol & GABA & $\begin{array}{l}\text { Passiflora extracts contain a large amount of GABA, and } \\
\text { can induce direct GABAA currents in cornu ammonis } 1 \\
\text { hippocampal pyramidal neurons }[72,74,75] \text {. }\end{array}$ \\
\hline Pimpinella anisum & Asia and so on & $\begin{array}{l}\text { In vivo and in vitro } \\
\text { models }\end{array}$ & Pentylenetetrazol & $\begin{array}{l}\mathrm{Na}^{+}-\mathrm{K}^{+} \text {ATPase and GABAA } \\
\text { receptors }\end{array}$ & $\begin{array}{l}\text { Enhances the activity of the Na+-K+ATPase, which inhibits } \\
\text { both GABAA and GABAB components of inhibitory post- } \\
\text { synaptic potentials [70]. }\end{array}$ \\
\hline Salvia miltiorrhiza & China & $\begin{array}{lr}\text { Animal } & \text { model } \\
\text { (Zebrafish } & \text { and } \\
\text { Mouse) } & \end{array}$ & Pentylenetetrazol & $\begin{array}{l}\text { GABA and related } \\
\text { Agonists }\end{array}$ & $\begin{array}{l}\text { A propensity to interact with path- ways irrelevant to GABA } \\
\text { and related agonists [10]. }\end{array}$ \\
\hline \multirow[t]{2}{*}{ skullcap } & $\begin{array}{l}\text { America, } \\
\text { Europe and }\end{array}$ & Animal model (rats) & Pentylenetetrazol & $\mathrm{GABA}_{\mathrm{A}}$ receptor & High affinity to GABAA receptor [77-9]. \\
\hline & China & & & Neuroprotective effects & $\begin{array}{l}\text { Neuroprotective effects mediated by anti-oxidation, anti- } \\
\text { inflamemation, and anti-excitotoxicity [77-79]. }\end{array}$ \\
\hline \multirow[t]{2}{*}{$\begin{array}{l}\text { Uncaria } \\
\text { rhynchophylla }\end{array}$} & China & Animal model(rats) & Kainic acid & $\begin{array}{l}\text { Pathways in both cortex and } \\
\text { hippocampus regions }\end{array}$ & $\begin{array}{l}\text { Exhibit anti-convulsive effects by regulating immune response } \\
\text { and neurotrophin signaling pathway [34]. }\end{array}$ \\
\hline & & & & Gene expression & $\begin{array}{l}\text { Ameliorate kainic acid-induced seizures by regulating } \\
\text { the expression of genes involved in neuron survival and } \\
\text { inflammation [34]. }\end{array}$ \\
\hline Viscum album & $\begin{array}{l}\text { Asia and } \\
\text { Europe }\end{array}$ & $\begin{array}{l}\text { Animal model } \\
\text { (mice and rats) }\end{array}$ & $\begin{array}{l}\text { Pentylenetetrazol } \\
\text { MES } \\
\text { Isonicotinic hydrazide acid }\end{array}$ & GABA & $\begin{array}{l}\text { Enhances the response to GABA, by facilitating the opening } \\
\text { of GABA-activated chloride channels [82]. }\end{array}$ \\
\hline \multirow[t]{5}{*}{ Zingiber officinale } & China and India & Animal model(rats) & Pentylenetetrazol & NO and iNOS & $\begin{array}{l}\text { Inhibits NO production and reduces iNOS in } \\
\text { lipopolysaccharide-stimulated mouse macrophages }[87,90] .\end{array}$ \\
\hline & & & & $\begin{array}{l}\text { NO/cGMP } \\
\text { Pathway }\end{array}$ & Elevated intracellular cGMP level [87]. \\
\hline & & & & $\begin{array}{l}\text { Chloride ion channel in the } \\
\text { complex of } \mathrm{GABA}_{\mathrm{A}} \text { receptors }\end{array}$ & $\begin{array}{l}\text { Inhibits Chloride ion channel in the complex of GABAA } \\
\text { receptors0 [87]. }\end{array}$ \\
\hline & & & & Calcium channel & Block calcium channel $[87,89]$. \\
\hline & & & & Antioxidant property & {$[87,88]$} \\
\hline \multirow[t]{4}{*}{ Zizyphus jujuba } & India & Animal model(rats) & Pentylenetetrazol & $\begin{array}{l}\text { Voltage-gated } \\
\text { Channel }\end{array}$ & Prolongs $\mathrm{Na}^{+}$channel inactivation [21]. \\
\hline & & & & GABA channel & Inhibits effect of GABA and reduce the excitation [21]. \\
\hline & & & & Glutamate and NMDA & $\begin{array}{l}\text { Inhibits glutamate-induced overexcitation, reduces synaptic } \\
\text { release of glutamate or NMDA }[20,21] \text {. }\end{array}$ \\
\hline & & & & Antioxidant effect & $\begin{array}{l}\text { Reverses antioxidant-oxidant imbalance by decreasing } \\
\text { NMDA levels and increasing glutathione levels [20]. }\end{array}$ \\
\hline
\end{tabular}

(Bryonia alba, Viscum album), high affinity to $\mathrm{GABA}_{\mathrm{A}}$ receptor (Euphorbiaceae, Lamiaceae, Apocynaceae, and skullcap), blockade of chloride ion channel linked to GABA receptors (Caesalpinia bonducella, Zingiber officinale), direct increase of GABA brain content (Gladiolus dalenii), and other ways to effect GABA and GABA receptors. Glutamate and Glutamate receptors are another significant drug target [91]. For instance, Lavandula officinalis prevents glutamate induced neurotoxicity of cerebellar granular cell culture of rat pups, Ficus platyphylla blocks glutamatergic neurotransmission mediated by the NMDA receptor, and Zizyphus jujuba inhibits glutamate-induced over-excitation and reduces synaptic release of glutamate or NMDA. Calcium channel and Sodium channel play a significant role in epilepsy, and also act as therapeutical drug targets for epilepsy. Lavandula stoechas and Lavandula officinalis block calcium channel. Ganoderma lucidum inhibits calcium overload to prevent an epileptic episode induced by $\mathrm{Mg}^{2+}$ deficiency. Ficus platyphylla and Ginseng inhibit L-type $\mathrm{Ca}^{2+}$ channels in hippocampal neurons, and Ginseng inhibits NMDA-dependent and status epilepticus induced $\mathrm{Ca}^{2+}$ influx. Oxidative stress is a cause or/and result of epileptic process, and oxidative damage can lead to neurodegeneration. A recent review has suggested that antioxidants express preventive effect on epilepsy [92]. In our paper, some herbal medicines have shown antioxidative effects by different pathways. Zizyphus jujube reverses antioxidant-oxidant imbalance by decreasing in NMDA levels and increasing glutathione levels. Ficus platyphylla scavenges action of free radicals (such as reactive oxygen and nitrogen species). Zingiber officinale inhibits Nitric oxide (NO) production and reduces inducible nitric oxide synthase (iNOS)in lipopolysaccharide-stimulated mouse macrophages. Some other mechanisms mediating antiepileptic effect have been listed in Table 1.

Besides, transient receptor potential banilloid type 1 (TRPV1) [93] and gap junction blockers [94], which have 
been reviewed in recent studies, are potential drug targets in epilepsy therapy. TRPV1, a calcium-permeable channel, is a cause of epilepsy and expressed in the hippocampus [75]. TRPV1 can be activated by oxidative stress, resiniferatoxin, cannabinoid receptor activators. Therefore, some herbal medicines may act on TRPV1; for instance, Cannabis. This hypothesis needs further investigation. Gap junctions are aggregations of intercellular channels and lead to hypersynchromous electrical activity which cause convulsive events [76]. These molecule mechanisms can be promising approaches to investigate herbal antiepileptic effect.

The pharmacological effects of herbal medicine on epilepsy exhibited discrepancy in epilepsy models. Epilepsy is a complicated pathophysiological process, and involves many mechanisms, which determine the complexity in the effects of herbal medicine on epilepsy. Though many studies have reported the efficacy of herbal medicine on epilepsy, there is a lack of clinical trial in the literature. Besides, the adverse effects of herbal medicine hinder the clinical medication. However, some herbal medicines are clinical use in some regions, especially China. Therefore, large samples, multi-center, doubleblind, randomized, controlled clinical trials are still further needed for future research. Actually, most of the herbal medicines in our review need further studies in mechanism of antiepileptic effect. The antiepileptic effects of some herbal medicine even need a scrutiny of efficacy. Meanwhile, the effective ingredients of the extract from herbal medicine should be examine in detail. Besides, a herbal medicine database should be set up in the future. It is a formidable work and need cooperation and efforts of researchers all over the world.

\section{SUMMARY}

The herbal medicine for epilepsy therapy is a worldwide clinical practice in folk or traditional medicine and modern western medicine. Hundreds of herbal medicines have been investigated in the available literatures. It's difficult to list all herbal medicine for epilepsy in one paper, so some common herbal medicines have been reviewed in our study. The overwhelming majority of these data are based on animal experiments. As data mentioned above, though the antiepileptic effects of some of them shown in animal experiments have been well documented, none of them to our knowledge has robust evidence for clinical medication. Besides, the efficacy and toxicity of the herbal medicine should be a subject to evidence-based scrutiny. However, there is a hard way to go. All of these factors place constraints on the clinical recommendation of herbal medicine. Some methodology technique and data reviewed in this paper may inspire further study and draw some light on the development of epilepsy drugs.

\section{Abbreviations}

GABA, gamma amino butyric acid, NMDA, N-methyl-D-aspartate, MES, maximal electroshock, BDNF, brain-derived neurotrophin factor, NO, Nitric oxide, iNOS, inducible nitric oxide synthase, TRPV1, transient receptor potential banilloid type 1 .

\section{ACKNOWLEDGMENTS AND FUNDING}

This work was supported by Natural Science Foundation of China (31571126 and 31300850).

\section{CONFLICTS OF INTEREST}

The authors confirm that this article content has no conflicts of interest.

\section{REFERENCES}

1. Liu X, Zeng YQ, Liang YZ, Zou C, Liu H, Qiu F, Liang CL, Jin XW, Su ZR, Dai Z. Medicinal herbs Fructus corni and Semen cuscutae suppress allograft rejection via distinct immune mechanisms. Oncotarget. 2016; 7:35680-91. doi: 10.18632/oncotarget.9680.

2. Sirven JI, Drazkowski JF, Zimmerman RS, Bortz JJ, Shulman DL, Macleish M. Complementary/alternative medicine for epilepsy in Arizona. Neurology. 2003; 61:576-77.

3. Zhang Y, Mao X, Guo Q, Bai M, Zhang B, Liu C, Sun Y, Li S, Lin N. Pathway of PPAR-gamma coactivators in thermogenesis: a pivotal traditional Chinese medicineassociated target for individualized treatment of rheumatoid arthritis. Oncotarget. 2016; 7:15885-900. doi: 10.18632/ oncotarget.7419.

4. Elferink JG. Epilepsy and its treatment in the ancient cultures of America. Epilepsia. 1999; 40:1041-46.

5. Shamaladevi N, Araki S, Lyn DA, Ayyathurai R, Gao J, Lokeshwar VB, Navarrete H, Lokeshwar BL. The andean anticancer herbal product BIRM causes destabilization of androgen receptor and induces caspase- 8 mediatedapoptosis in prostate cancer. Oncotarget. 2016; 7:84201-13. doi: 10.18632/oncotarget.12393.

6. Wong V, Chung BH. Survey of public awareness, attitudes, and understanding toward epilepsy in Hong Kong. Epilepsia. 2003; 44:268-69.

7. Chung MY, Chang YC, Lai YH, Lai CW. Survey of public awareness, understanding, and attitudes toward epilepsy in Taiwan. Epilepsia. 1995; 36:488-93.

8. Schachter SC. Botanicals and herbs: a traditional approach to treating epilepsy. Neurotherapeutics. 2009; 6:415-20.

9. Sucher NJ. Insights from molecular investigations of traditional Chinese herbal stroke medicines: implications for neuroprotective epilepsy therapy. Epilepsy Behav. 2006; 8:350-62. 
10. Buenafe OE, Orellana-Paucar A, Maes J, Huang H, Ying $\mathrm{X}$, De Borggraeve W, Crawford AD, Luyten W, Esguerra $\mathrm{CV}$, de Witte P. Tanshinone IIA exhibits anticonvulsant activity in zebrafish and mouse seizure models. ACS Chem Neurosci. 2013; 4:1479-87.

11. Sahranavard S, Ghafari S, Mosaddegh M. Medicinal plants used in Iranian traditional medicine to treat epilepsy. Seizure. 2014; 23:328-32.

12. Bagheri SM, Sahebkar A, Gohari AR, Saeidnia S, Malmir M, Iranshahi M. Evaluation of cytotoxicity and anticonvulsant activity of some Iranian medicinal Ferula species. Pharm Biol. 2010; 48:242-46.

13. Gilani AH, Aziz N, Khan MA, Shaheen F, Jabeen Q, Siddiqui BS, Herzig JW. Ethnopharmacological evaluation of the anticonvulsant, sedative and antispasmodic activities of Lavandula stoechas L. J Ethnopharmacol. 2000; 71:161-67.

14. Ali A, Rao NV, Shalam MD, Shantakumar SM. Anticonvulsive effect of seed extract of Caesalpinia bonducella (Roxb.). Iran J Pharmacol Ther. 2009; 51-5.

15. Salah SM, Jäger AK. Screening of traditionally used Lebanese herbs for neurological activities. J Ethnopharmacol. 2005; 97:145-49.

16. Rahmati B, Khalili M, Roghani M, Ahghari P. Antiepileptogenic and antioxidant effect of Lavandula officinalis aerial part extract against pentylenetetrazol-induced kindling in male mice. J Ethnopharmacol. 2013; 148:152-57.

17. Gilani AH, Aziz N, Khan MA, Shaheen F, Jabeen Q, Siddiqui BS, Herzig JW. Ethnopharmacological evaluation of the anticonvulsant, sedative and antispasmodic activities of Lavandula stoechas L. J Ethnopharmacol. 2000; 71:161-67.

18. Büyükokuroğlu ME, Gepdiremen A, Hacimüftüoğlu A, Oktay M. The effects of aqueous extract of Lavandula angustifolia flowers in glutamate-induced neurotoxicity of cerebellar granular cell culture of rat pups. J Ethnopharmacol. 2003; 84:91-94.

19. Silva Brum LF, Emanuelli T, Souza DO, Elisabetsky E. Effects of linalool on glutamate release and uptake in mouse cortical synaptosomes. Neurochem Res. 2001; 26:191-94.

20. Pahuja M, Mehla J, Reeta KH, Joshi S, Gupta YK. Hydroalcoholic extract of Zizyphus jujuba ameliorates seizures, oxidative stress, and cognitive impairment in experimental models of epilepsy in rats. Epilepsy Behav. 2011; 21:356-63.

21. Pahuja M, Kleekal T, Reeta KH, Tripathi M, Gupta YK. Interaction profile of Zizyphus jujuba with phenytoin, phenobarbitone, and carbamazepine in maximal electroshock-induced seizures in rats. Epilepsy Behav. 2012; 25:368-73.

22. Ahmed B. Distribution, morphology and medicinal uses of Taxus baccata. Hamdard Med. 1997; 20:53-54.

23. Nisar M, Khan I, Simjee SU, Gilani AH, Obaidullah, Perveen H. Anticonvulsant, analgesic and antipyretic activities of Taxus wallichiana Zucc. J Ethnopharmacol. 2008; 116:490-94.
24. Wang SQ, Li XJ, Zhou S, Sun DX, Wang H, Cheng PF, Ma XR, Liu L, Liu JX, Wang FF, Liang YF, Wu JM. Intervention effects of ganoderma lucidum spores on epileptiform discharge hippocampal neurons and expression of neurotrophin-4 and N-cadherin. PLoS One. 2013; 8:e61687.

25. Socala K, Nieoczym D, Grzywnowicz K, Stefaniuk D, Wlaz P. Evaluation of Anticonvulsant, Antidepressant-, and Anxiolytic-like Effects of an Aqueous Extract from Cultured Mycelia of the Lingzhi or Reishi Medicinal Mushroom Ganoderma lucidum (Higher Basidiomycetes) in Mice. Int J Med Mushrooms. 2015; 17:209-18.

26. Tello I, Campos-Pena V, Montiel E, Rodriguez V, AguirreMoreno A, Leon-Rivera I, Del Rio-Portilla F, HerreraRuiz M, Villeda-Hernandez J. Anticonvulsant and neuroprotective effects of oligosaccharides from Lingzhi or Reishi medicinal mushroom, Ganoderma lucidum (Higher Basidiomycetes). Int J Med Mushrooms. 2013; 15:555-68.

27. Wang SQ, Li XJ, Qiu HB, Jiang ZM, Simon M, Ma XR, Liu L, Liu JX, Wang FF, Liang YF, Wu JM, Di WH, Zhou S. Anti-epileptic effect of Ganoderma lucidum polysaccharides by inhibition of intracellular calcium accumulation and stimulation of expression of CaMKII $\alpha$ in epileptic hippocampal neurons. PLoS One. 2014; 9:e102161.

28. MacLaren R, Forrest LK, Kiser TH. Adjunctive dexmedetomidine therapy in the intensive care unit: a retrospective assessment of impact on sedative and analgesic requirements, levels of sedation and analgesia, and ventilatory and hemodynamic parameters. Pharmacotherapy. 2007; 27:351-59.

29. Lo WY, Tsai FJ, Liu CH, Tang NY, Su SY, Lin SZ, Chen CC, Shyu WC, Hsieh CL. Uncaria rhynchophylla upregulates the expression of MIF and cyclophilin A in kainic acid-induced epilepsy rats: A proteomic analysis. Am J Chin Med. 2010; 38:745-59.

30. Hsieh CL, Ho TY, Su SY, Lo WY, Liu CH, Tang NY. Uncaria rhynchophylla and Rhynchophylline inhibit c-Jun $\mathrm{N}$-terminal kinase phosphorylation and nuclear factorkappaB activity in kainic acid-treated rats. Am J Chin Med. 2009; 37:351-60.

31. Hsieh CL, Chen MF, Li TC, Li SC, Tang NY, Hsieh CT, Pon CZ, Lin JG. Anticonvulsant effect of Uncaria rhynchophylla (Miq) Jack. in rats with kainic acid-induced epileptic seizure. Am J Chin Med. 1999; 27:257-64.

32. Yuan D, Ma B, Yang JY, Xie YY, Wang L, Zhang LJ, Kano Y, Wu CF. Anti-inflammatory effects of rhynchophylline and isorhynchophylline in mouse N9 microglial cells and the molecular mechanism. Int Immunopharmacol. 2009; 9:1549-54.

33. Xian YF, Lin ZX, Mao QQ, Hu Z, Zhao M, Che CT, Ip SP. Bioassay-Guided Isolation of Neuroprotective Compounds from Uncaria rhynchophylla against Beta-Amyloid-Induced Neurotoxicity. Evid Based Complement Alternat Med. 2012; 2012:802625. 
34. Ho TY, Tang NY, Hsiang CY, Hsieh CL. Uncaria rhynchophylla and rhynchophylline improved kainic acidinduced epileptic seizures via IL-1 $\beta$ and brain-derived neurotrophic factor. Phytomedicine. 2014; 21:893-900.

35. Ma R, Li S, Li X, Hu S, Sun X, Liu Y, Zhang X, Li X, Ma $\mathrm{X}$. Clinical observation on 930 child epilepsy cases treated with anti-epilepsy capsules. J Tradit Chin Med. 2003; 23:109-12.

36. Ren XQ, Ma R, Yang CQ, Liu QH, Jiao J, Zhang XL, Rong P. Kangxian capsules: effects on convulsive injuries, N-methyl-d-aspartate (NMDA) receptor subunit expression, and free $\mathrm{Ca}(2+)$ concentration in a rat hippocampal neuron epileptic discharge model. Seizure. 2016; 40:27-32.

37. Bum EN, Taiwe GS, Nkainsa LA, Moto FC, Seke Etet PF, Hiana IR, Bailabar T, Rouyatou, Seyni P, Rakotonirina A, Rakotonirina SV. Validation of anticonvulsant and sedative activity of six medicinal plants. Epilepsy Behav. 2009; 14:454-58.

38. Salih MA, Mustafa AA. A substance in broad beans (Vicia faba) is protective against experimentally induced convulsions in mice. Epilepsy Behav. 2008; 12:25-29.

39. Holmes GL. Animal model studies application to human patients. Neurology. 2007 (Suppl 3); 69:S28-32.

40. Risa J, Risa A, Adsersen A, Gauguin B, Stafford GI, van Staden J, Jäger AK. Screening of plants used in southern Africa for epilepsy and convulsions in the GABAAbenzodiazepine receptor assay. J Ethnopharmacol. 2004; 93:177-82.

41. Chindo BA, Ya'U J, Danjuma NM, Okhale SE, Gamaniel KS, Becker A. Behavioral and anticonvulsant effects of the standardized extract of Ficus platyphylla stem bark. J Ethnopharmacol. 2014; 154:351-60.

42. Chindo BA, Schröder H, Becker A. Methanol extract of Ficus platyphylla ameliorates seizure severity, cognitive deficit and neuronal cell loss in pentylenetetrazole-kindled mice. Phytomedicine. 2015; 22:86-93.

43. Chindo BA, Anuka JA, McNeil L, Yaro AH, Adamu SS, Amos S, Connelly WK, Lees G, Gamaniel KS. Anticonvulsant properties of saponins from Ficus platyphylla stem bark. Brain Res Bull. 2009; 78:276-82.

44. Chindo BA, Anuka JA, Gamaniel KS. Toxicity screenings of Ficus platyphylla stem bark in rats. Pharmacologia. 2012; 3.

45. Ngoupaye GT, Bum EN, Taiwe GS, Moto FC, Talla E. Antidepressant properties of aqueous macerate from Gladiolus dalenii corms. Afr J Tradit Complement Altern Med. 2013; 11:53-61.

46. Ngoupaye GT, Bum EN, Daniels WM. Antidepressant-like effects of the aqueous macerate of the bulb of Gladiolus dalenii Van Geel (Iridaceae) in a rat model of epilepsyassociated depression. BMC Complement Altern Med. $2013 ; 13: 272$.

47. Ngoupaye GT, Ngo Bum E, Ngah E, Talla E, Moto FC, Taiwe GS, Rakotonirina A, Rakotonirina SV. The anticonvulsant and sedative effects of Gladiolus dalenii extracts in mice. Epilepsy Behav. 2013; 28:450-56.

48. Pearl PL, Drillings IM, Conry JA. Herbs in epilepsy: evidence for efficacy, toxicity, and interactions. Semin Pediatr Neurol. 2011; 18:203-08.

49. Spinella M. Herbal Medicines and Epilepsy: The Potential for Benefit and Adverse Effects. Epilepsy Behav. 2001; 2:524-32.

50. Volz HP, Kieser M. Kava-kava extract WS 1490 versus placebo in anxiety disorders - a randomized placebocontrolled 25-week outpatient trial. Pharmacopsychiatry. 1997; 30:1-5.

51. Devinsky O, Cilio MR, Cross H, Fernandez-Ruiz J, French J, Hill C, Katz R, Di Marzo V, Jutras-Aswad D, Notcutt WG, Martinez-Orgado J, Robson PJ, Rohrback BG, et al. Cannabidiol: pharmacology and potential therapeutic role in epilepsy and other neuropsychiatric disorders. Epilepsia. 2014; 55:791-802.

52. Bahremand A, Shafaroodi H, Ghasemi M, Nasrabady SE, Gholizadeh S, Dehpour AR. The cannabinoid anticonvulsant effect on pentylenetetrazole-induced seizure is potentiated by ultra-low dose naltrexone in mice. Epilepsy Res. 2008; 81:44-51.

53. Jones NA, Hill AJ, Smith I, Bevan SA, Williams CM, Whalley BJ, Stephens GJ. Cannabidiol displays antiepileptiform and antiseizure properties in vitro and in vivo. J Pharmacol Exp Ther. 2010; 332:569-77.

54. Hill AJ, Mercier MS, Hill TD, Glyn SE, Jones NA, Yamasaki Y, Futamura T, Duncan M, Stott CG, Stephens GJ, Williams CM, Whalley BJ. Cannabidivarin is anticonvulsant in mouse and rat. Br J Pharmacol. 2012; 167:1629-42.

55. Hussain SA, Zhou R, Jacobson C, Weng J, Cheng E, Lay J, Hung P, Lerner JT, Sankar R. Perceived efficacy of cannabidiol-enriched cannabis extracts for treatment of pediatric epilepsy: A potential role for infantile spasms and Lennox-Gastaut syndrome. Epilepsy Behav. 2015; 47:138-41.

56. Press CA, Knupp KG, Chapman KE. Parental reporting of response to oral cannabis extracts for treatment of refractory epilepsy. Epilepsy Behav. 2015; 45:49-52.

57. Reddy DS, Golub VM. The Pharmacological Basis of Cannabis Therapy for Epilepsy. J Pharmacol Exp Ther. 2016; 357:45-55.

58. Colasanti BK, Lindamood C 3rd, Craig CR. Effects of marihuana cannabinoids on seizure activity in cobaltepileptic rats. Pharmacol Biochem Behav. 1982; 16:573-78.

59. Jones NA, Hill AJ, Smith I, Bevan SA, Williams CM, Whalley BJ, Stephens GJ. Cannabidiol displays antiepileptiform and antiseizure properties in vitro and in vivo. J Pharmacol Exp Ther. 2010; 332:569-77.

60. Jones NA, Glyn SE, Akiyama S, Hill TD, Hill AJ, Weston SE, Burnett MD, Yamasaki Y, Stephens GJ, Whalley BJ, Williams CM. Cannabidiol exerts anti-convulsant effects 
in animal models of temporal lobe and partial seizures. Seizure. 2012; 21:344-52.

61. Bergamaschi MM, Queiroz RH, Zuardi AW, Crippa JA. Safety and side effects of cannabidiol, a Cannabis sativa constituent. Curr Drug Saf. 2011; 6:237-49.

62. Kim P, Park JH, Kwon KJ, Kim KC, Kim HJ, Lee JM, Kim HY, Han SH, Shin CY. Effects of Korean red ginseng extracts on neural tube defects and impairment of social interaction induced by prenatal exposure to valproic acid. Food Chem Toxicol. 2013; 51:288-96.

63. Suleymanova E, Gulyaev M, Chepurnova N. Ginseng extract attenuates early MRI changes after status epilepticus and decreases subsequent reduction of hippocampal volume in the rat brain. Epilepsy Res. 2014; 108:223-31.

64. Lian XY, Zhang ZZ, Stringer JL. Anticonvulsant activity of ginseng on seizures induced by chemical convulsants. Epilepsia. 2005; 46:15-22.

65. Liu Y, Lo YC, Qian L, Crews FT, Wilson B, Chen HL, Wu HM, Chen SH, Wei K, Lu RB, Ali S, Hong JS. Verapamil protects dopaminergic neuron damage through a novel anti-inflammatory mechanism by inhibition of microglial activation. Neuropharmacology. 2011; 60:373-80.

66. Lin ZY, Chen LM, Zhang J, Pan XD, Zhu YG, Ye QY, Huang HP, Chen XC. Ginsenoside Rb1 selectively inhibits the activity of L-type voltage-gated calcium channels in cultured rat hippocampal neurons. Acta Pharmacol Sin. 2012; 33:438-44.

67. Gorji A, Khaleghi Ghadiri M. History of epilepsy in Medieval Iranian medicine. Neurosci Biobehav Rev. 2001; 25:455-61.

68. Pourgholami MH, Majzoob S, Javadi M, Kamalinejad M, Fanaee GH, Sayyah M. The fruit essential oil of Pimpinella anisum exerts anticonvulsant effects in mice. J Ethnopharmacol. 1999; 66:211-15.

69. Karimzadeh F, Hosseini M, Mangeng D, Alavi H, Hassanzadeh GR, Bayat M, Jafarian M, Kazemi H, Gorji A. Anticonvulsant and neuroprotective effects of Pimpinella anisum in rat brain. BMC Complement Altern Med. 2012; 12:76.

70. Pourgholami MH, Majzoob S, Javadi M, Kamalinejad M, Fanaee GH, Sayyah M. The fruit essential oil of Pimpinella anisum exerts anticonvulsant effects in mice. J Ethnopharmacol. 1999; 66:211-15.

71. Elsas SM, Rossi DJ, Raber J, White G, Seeley CA, Gregory WL, Mohr C, Pfankuch T, Soumyanath A. Passiflora incarnata L. (Passionflower) extracts elicit GABA currents in hippocampal neurons in vitro, and show anxiogenic and anticonvulsant effects in vivo, varying with extraction method. Phytomedicine. 2010; 17:940-49.

72. Singh B, Singh D, Goel RK. Dual protective effect of Passiflora incarnata in epilepsy and associated post-ictal depression. J Ethnopharmacol. 2012; 139:273-79.

73. Koh EM, Kim HJ, Kim S, Choi WH, Choi YH, Ryu SY, Kim YS, Koh WS, Park SY. Modulation of macrophage functions by compounds isolated from Zingiber officinale. Planta Med. 2009; 75:148-51.

74. Montgomery SA. Antidepressants and seizures: emphasis on newer agents and clinical implications. Int J Clin Pract. 2005; 59:1435-40.

75. Mula M, Schmitz B. Depression in epilepsy: mechanisms and therapeutic approach. Ther Adv Neurol Disorder. 2009; 2:337-44.

76. Wolfson P, Hoffmann DL. An investigation into the efficacy of Scutellaria lateriflora in healthy volunteers. Altern Ther Health Med. 2003; 9:74-78.

77. Liu LY, Wei EQ, Zhao YM, Chen FX, Wang ML, Zhang WP, Chen Z. Protective effects of baicalin on oxygen/ glucose deprivation- and NMDA-induced injuries in rat hippocampal slices. J Pharm Pharmacol. 2005; 57:1019-26.

78. Zhang Z, Lian XY, Li S, Stringer JL. Characterization of chemical ingredients and anticonvulsant activity of American skullcap (Scutellaria lateriflora). Phytomedicine. 2009; 16:485-93.

79. Wang H, Hui KM, Chen Y, Xu S, Wong JT, Xue H. Structureactivity relationships of flavonoids, isolated from Scutellaria baicalensis, binding to benzodiazepine site of GABA(A) receptor complex. Planta Med. 2002; 68:1059-62.

80. Zuber D. Biological flora of Central Europe: viscum album L. Flora. 2004; 199:181-82.

81. von Schoen-Angerer T, Madeleyn R, Kienle G, Kiene H, Vagedes J, and von ST. Viscum Album in the Treatment of a Girl With Refractory Childhood Absence Epilepsy. J Child Neurol. 2015; 30:1048-52.

82. Gupta G, Kazmi I, Afzal M, Rahman M, Saleem S, Ashraf MS, Khusroo MJ, Nazeer K, Ahmed S, Mujeeb M, Ahmed Z, Anwar F. Sedative, antiepileptic and antipsychotic effects of Viscum album L. (Loranthaceae) in mice and rats. J Ethnopharmacol. 2012; 141:810-16.

83. Ojewole JA. Analgesic, antiinflammatory and hypoglycaemic effects of ethanol extract of Zingiber officinale (Roscoe) rhizomes (Zingiberaceae) in mice and rats. Phytother Res. 2006; 20:764-72.

84. Nanjundaiah SM, Annaiah HN, Dharmesh SM. Gastroprotective Effect of Ginger Rhizome (Zingiber officinale) Extract: Role of Gallic Acid and Cinnamic Acid in H (), K ()-ATPase/H. pylori Inhibition and AntiOxidative Mechanism. Evid Based Complement Alternat Med. 2011; 2011:249487.

85. Shanmugam KR, Mallikarjuna K, Kesireddy N, Sathyavelu Reddy K. Neuroprotective effect of ginger on anti-oxidant enzymes in streptozotocin-induced diabetic rats. Food Chem Toxicol. 2011; 49:893-97.

86. Hosseini A, Mirazi N. Alteration of pentylenetetrazoleinduced seizure threshold by chronic administration of ginger (Zingiber officinale) extract in male mice. Pharm Biol. 2015; 53:752-57.

87. Hosseini A, Mirazi N. Acute administration of ginger (Zingiber officinale rhizomes) extract on timed intravenous pentylenetetrazol infusion seizure model in mice. Epilepsy Res. 2014; 108:411-19. 
88. Ghasemzadeh A, Jaafar HZ, Rahmat A. Antioxidant activities, total phenolics and flavonoids content in two varieties of Malaysia young ginger (Zingiber officinale Roscoe). Molecules. 2010; 15:4324-33.

89. Popova J, Staneva-Stoytcheva D, Mutafova V. Effects of the $\mathrm{Ca} 2(+)$-antagonists nifedipine, verapamil, flunarizine and of the calmodulin antagonist trifluoperazine on muscarinic cholinergic receptors in rat cerebral cortex. Gen Pharmacol. 1990; 21:317-19.

90. Koh EM, Kim HJ, Kim S, Choi WH, Choi YH, Ryu SY, Kim YS, Koh WS, Park SY. Modulation of macrophage functions by compounds isolated from Zingiber officinale. Planta Med. 2009; 75:148-51.
91. Qian F, Tang FR. Metabotropic Glutamate Receptors and Interacting Proteins in Epileptogenesis. Curr Neuropharmacol. 2016; 14:551-62.

92. Martinc B, Grabnar I, Vovk T. Antioxidants as a preventive treatment for epileptic process: a review of the current status. Curr Neuropharmacol. 2014; 12:527-50.

93. Nazıroğlu M. TRPV1 Channel: A Potential Drug Target for Treating Epilepsy. Curr Neuropharmacol. 2015; 13:239-47.

94. Manjarrez-Marmolejo J, Franco-Pérez J. Gap Junction Blockers: An Overview of their Effects on Induced Seizures in Animal Models. Curr Neuropharmacol. 2016; 14:759-71. 